\title{
A SALA DE AULA INVERTIDA E O LÚDICO NO ENSINO REMOTO DE ITALIANO: ATIVIDADES PROPOSTAS
}

\author{
La classe capovolta e la didattica ludica \\ nell'insegnamento remoto di italiano: attività \\ proposte
}

\section{The Flipped Classroom and the Ludic Pedagogy in an Italian Remote Learning Program: Proposed Activities}

\author{
Cleide Giacomelli Borraz* \\ Meluina Anastacio Silva * * \\ Telmo AmbrosinI ** \\ DANIELA BUNN***
}

RESUMO: Este artigo tem como objetivo apresentar as propostas de atividades que possibilitaram a interação dos alunos inscritos no projeto de extensão Italiano per Tutti, realizado em modalidade remota, durante dois semestres. O curso ofertado foi dividido entre aulas síncronas, via plataforma Zoom, e aulas assíncronas, construídas e disponibilizadas no Ambiente Virtual Moodle. As aulas abordaram, além de noções básicas da língua italiana, temáticas (inter)culturais. Os princípios norteadores basearam-se nas Metodologias Ativas (VALENTE, 2014), com ênfase na Sala de Aula Invertida (BERGMANN, 2016; LACERDA, 2018) e na utilização do lúdico (PESSOLANO, 2018) a fim de que as atividades propostas pudessem instigar os alunos a participarem de maneira mais ativa do processo de aprendizagem (SILVA, 2004). Buscou-se evidenciar tais atividades visando a elaboração e a utilização na prática, bem como a reflexão sobre a importância do lúdico no ensino remoto.

PALAVRAS-CHAVE: Metodologias ativas; Ensino remoto; Sala de aula invertida; Ludicidade; Engajamento.

*Graduanda em Letras - Universidade Federal de Santa Catarina cleidegiacomelli@gmail.com (ORCID: 0000-0001-9279-882X)

**Graduanda em Letras - Universidade Federal de Santa Catarina

anastaciomellina@gmail.com (ORCID: 0000-0002-8746-6166)

***Graduando em Letras - Universidade Federal de Santa Catarina

telmo.ambrosini@gmail.com (ORCID: 0000-0003-4667-4732)

****Docente - Universidade Federal de Santa Catarina

daniela.bunn@ufsc.br (ORCID: 0000-0002-3072-7599)

DOI: http://dx.doi.org/10.11606/issn.2238-8281.v0i42p92-112

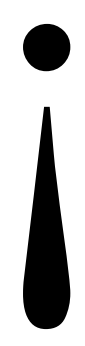


ABSTRACT: Questo articolo ha l'obiettivo di presentare le proposte di attività che hanno permesso agli studenti iscritti al progetto di estensione Italiano per Tutti di svolgere il corso a distanza per due semestri. Il corso offerto è stato diviso tra lezioni sincrone, tramite la piattaforma Zoom, e lezioni asincrone, realizzate e rese disponibili nell'Ambiente Virtuale Moodle. Le lezioni hanno riguardato, oltre ai concetti di base della lingua italiana, argomenti (inter)culturali. I principi guida sono basati sulle Metodologie Attive (VALENTE, 2014), con enfasi sulla Classe Capovolta (LACERDA, 2018), e sull'uso della didattica ludica (PESSOLANO, 2018), in modo che le attività proposte potessero incoraggiare gli studenti a partecipare più attivamente al corso (SILVA, 2004). Si è cercato, quindi, di analizzare tali attività mirando alla loro elaborazione e utilizzazione nella pratica, così come alla riflessione sull'importanza del ludico nell'insegnamento remoto.

PAROLE CHIAVE: Metodologie attive; Insegnamento remoto; Classe capovolta; Didattica ludica; Coinvolgimento.

ABSTRACT: This article aims to present the activities that made possible the interaction among the students enrolled in the extension project Italiano per Tutti, performed online for two semesters. The course was divided into synchronous classes, via Zoom, and asynchronous classes, given and made available on Moodle. The classes addressed, in addition to basic notions of Italian language, also (inter)cultural topics. The guiding principles were based on Active Methodologies (VALENTE, 2014), with emphasis on the concept of Inverted/Flipped Classroom (BERGMANN, 2016; LACERDA, 2018) and on the use of Ludic Pedagogy (PESSOLANO, 2018), so that the proposed activities could instigate students to participate more actively in the learning process (SILVA, 2004). We intended to analyze such activities emphasizing their elaboration and practical use, as well as the reflection on the importance of ludic in remote learning.

KEYWORDS: Active methodologies; Remote learning; Flipped classroom; Ludic pedagogy; Engagement. 


\section{Introdução}

Insegnare non è trasferire conoscenza, ma creare le possibilità per la sua propria produzione o la sua costruzione.

(Paulo Freire)

A realidade da oferta do ensino regular de italiano no sul do Brasil, em específico no Estado de Santa Catarina, ao contrário do que se imagina, não é assim tão fértil. Atualmente, segundo Oliveira (2021), apenas três escolas Estaduais, de um total de 1144, oferecem ensino regular de italiano, envolvendo 214 alunos - poucos, se levarmos em conta a realidade plurilíngue do Estado e a composição étnica da região. Embora em número menos expressivo, como relata a pesquisadora, o italiano (assim como o alemão e o espanhol) resistem, de certa maneira, "à minorização que decorre da hegemonia imposta" (OLIVEIRA, 2021, p. 420). Num ato de resistência e engajamento, é necessário preparar a terra, corrigir o solo, fertilizar e plantar sementes não só na escola, mas nos lugares ao seu redor com intuito de que germinem e proliferem. É assim que organizamos os Estágios Supervisionados Curriculares da Universidade Federal de Santa Catarina (UFSC), vinculados ao Centro de Ciências e Educação, criando espaços alternativos para democratização da língua italiana na grande Florianópolis. Organizações sem fins lucrativos, Centros Comunitários, Núcleo de Idosos, Universidades, Institutos, Escolas eram nossos desafios de difusão da língua em contexto presencial, alternativas que forneciam as mais variadas experiências para os professores em formação e valorizavam cada vez mais a experiência do estágio obrigatório.

Em 2019, os alunos participantes deste relato cursaram a disciplina de Metodologia de Ensino do Italiano e desenvolveram projetos de estágios individuais, voltados para públicos e locais específicos. Nesse mesmo ano foi criado o projeto de extensão Italiano per tutti - língua italiana na escola pública entre a tradição e a atualidade no qual esta experiência foi inserida. A chegada da pandemia do Novo Coronavírus (SARS-Cov-2), no início de 2020, impossibilitou a realização desses projetos, que teriam ocorrido no Centro Comunitário do Bairro Rio Tavares, num projeto voltado para a saúde bucal e o ensino de italiano para crianças, com base no livro Mariolino e Luigino (Cuca Fresca, 2011), no Colégio de Aplicação da Universidade Federal de Santa Catarina, num projeto para o primeiro ciclo do Ensino Fundamental, com base no livro Ho i mostriciattoli nella pancia (UFPR, 2018) e no Colégio Estadual Francisco Mazzola, em Nova Trento, num curso ofertado aos alunos do Ensino Médio do Curso de Turismo e Hospitalidade sobre noções básicas da língua. Mesmo com projetos já em fase de elaboração, o isolamento social e a suspensão das aulas presenciais levaram-nos à busca de um novo campo de estágio. O desafio era então como criar, segundo Paulo Freire, possibilidades para a construção de conhecimentos, em um universo virtual que nos parecia tão distante de tudo que havíamos planejado. 
Apesar do retorno das aulas da UFSC em formato remoto, o Decreto 630/2020 do Estado de Santa Catarina proibia os estágios curriculares nas escolas em formato não-presencial. Nesse ínterim, na busca por novas terras férteis, as equipes de estagiários do Italiano e também do Francês foram acolhidas pelo Instituto Federal de Santa Catarina (IFSC). Realizamos uma sondagem, denominada Cadastro de Interesse, via Formulários Google, para diagnosticar tanto o interesse da comunidade escolar em aulas italiano em modo virtual como suas motivações. A equipe, composta por cinco estagiários e a professora orientadora, foi surpreendida com 274 interessados na língua italiana, das faixas etárias mais distintas, em sua maioria jovens abaixo dos 23 anos (Gráfico 1), dos quais 74,8\% eram alunos, a maioria do Ensino Médio Técnico Integrado e da Graduação. Seguindo os preceitos da Instituição, numa perspectiva inclusiva, foram abertas duas turmas de italiano de nível básico, com turmas mistas, compostas por alunos do Ensino Médio Técnico (Integrado, Concomitante e Subsequente), professores e técnicos administrativos. Nos Gráficos 1 e 2 podemos acompanhar a faixa etária de interesse, com uma parcela bem jovem, bem como as principais motivações descritas em relação ao estudo da língua italiana: o interesse na língua e na cultura, seguido por laços familiares e descendência.

Gráfico 1 - Google Forms. Cadastro de interesse. Título da pergunta: Faixa etária.

Faixa etária

274 respostas

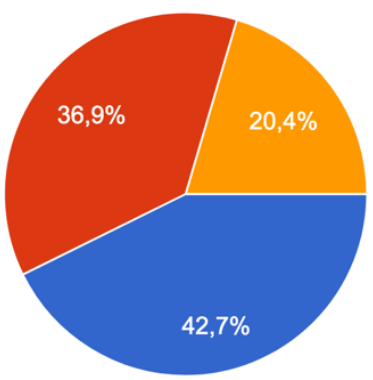

16-23 anos

24-40 anos

41 ou mais

Fonte: Google Forms (2020) 
Gráfico 2 - Google Forms. Cadastro de interesse. Título da pergunta: Objetivos em relação ao curso.

Qual o seu objetivo principal com o curso?

274 respostas

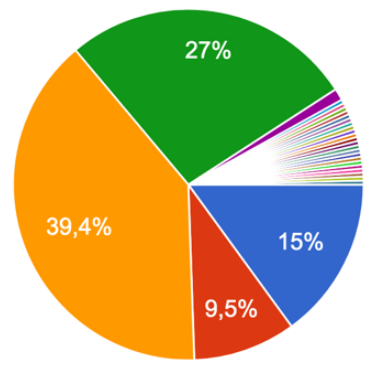

Viagem/Lazer

Trabalho

Estudo

Família/Cidadania

Trabalho, viagem e estudo

Vontade de aprender novos idiomas

Trabalho, amigos, estudo

Curiosidade e vontade de aprender

$1 / 4 \nabla$

Fonte: Google Forms (2020)

Após o processo de acolhimento na Instituição, com reuniões formativas para que pudéssemos conhecer os preceitos sócio-construtivistas que embasam a relação da Instituição com a comunidade, abrimos a oferta para dois cursos de nível básico, com 212 pessoas inscritas para o sorteio das 40 vagas. O sorteio das vagas ocorreu via live do Instagram (@italianopertutti.ufsc), de forma lúdica, com a utilização da Tômbola, jogo tradicional italiano, de tradição napolitana, no qual os números são colocados dentro de um pequeno cesto com a forma do vulcão Vesúvio e correspondente a um símbolo ou palavra. A ideia foi envolver os inscritos na cultura e na língua, pois além de se explicar brevemente como é utilizada a Tômbola, e sua forte presença nas festas natalinas italianas, os números de 1 a 90, foram falados em napolitano, italiano e em português, com condução de uma das estagiárias.

Demos então início aos cursos. A experiência que se narra, a partir do desafio de ressaltar como o lúdico foi trabalhado no ensino remoto, faz parte do subprojeto de docência intitulado Italia - Lingua e Cultura. As atividades aconteceram em dois momentos: 2020.1 com uma turma (Nível 1) de 20 alunos e 2020.2 com uma turma (Nível 2) de 40 alunos, percebemos que a evasão no ensino remoto deve ser levada em conta na definição do número de participantes acolhidos nos grupos. No segundo curso optamos por fazer a inscrição automática via sistema UFSC e recebemos tanto os participantes do primeiro curso como outros que já possuíam um nível básico da língua. 


\section{Italia - Lingua e Cultura}

Diante deste novo cenário, deparamo-nos com a necessidade de buscar metodologias que pudessem agregar ao ensino remoto e também, de certa forma, contribuir para que a aprendizagem fosse gradativa e motivadora. Logo, encontramos nas Metodologias Ativas possibilidades a serem trabalhadas e adaptadas para o contexto virtual. Entre as Metodologias Ativas, trabalhamos com a proposta da Sala de Aula Invertida (classe capovolta), abordagem escolhida e adaptada para construção do projeto em questão, na qual o aluno entra em contato com o material disponibilizado anteriormente e o estuda, tornando a aula em si um lugar de aprendizagem ativa, onde há perguntas, discussões e atividades práticas (VALENTE, 2014, p. 86).

Cada Metodologia Ativa possui abordagens e ferramentas diferenciadas, mas observamos que a ludicidade está presente na maioria delas. O lúdico, para além dos jogos e divertimento, busca a interação dos alunos permitindo a exploração de um ambiente mais descontraído em sala de aula, além de extrapolar

[...] qualquer visão simplista adotada por defensores de modelos pedagógicos cujos resultados permanecem pouco questionados. Tarefas que focalizam situações imaginárias como o role play, por exemplo, favorecem o desenvolvimento do pensamento abstrato, além de promoverem a circulação de input lingüístico [sic] autêntico. As situações, autorizadas por regras sociais capazes de gerar ações questionadoras por parte dos sujeitos envolvidos, tornam-se alvo certo de um bom ensino comunicativo de línguas (PESSOLANO, 2018, p.5)

Sendo assim, o projeto Italia - Lingua e Cultura teve como base o primeiro contato com a língua italiana de forma lúdica e informativa, a fim de instigar os estudantes a aprenderem mais sobre a língua. Idealizado para abranger os mais variados públicos do universo do campo de estágio, visa oportunizar democraticamente o aprendizado da língua italiana, que compõe a identidade de muitos habitantes da grande Florianópolis. Por meio da apresentação de elementos componentes da cultura do país, bem como de vocabulário e estruturas gramaticais que permitam a comunicação em nível básico, o projeto voltou-se para a reapresentação da Itália: não aquela que muitos guardam melancolicamente na lembrança como o país de origem de seus antepassados, mas a Itália contemporânea, que acontece, a Itália possível para nós, que polemiza assuntos delicados como a imigração, por exemplo. Embora não selecionada como foco para esse relato, a Interculturalidade e a Lei 11645 perpassaram nossas discussões.

Foram criadas e/ou adaptadas, então, atividades para que os alunos pudessem se comunicar em situações básicas da língua e conhecessem um pouco sobre os elementos formadores da cultura da Itália contemporânea, um desafio em tempos de ensino remoto. Ao longo deste artigo, procuraremos contextualizar nossa experiência e trazer propostas de atividades das quais trabalhamos e desenvolvemos para a nossa realidade atual. As aulas foram realizadas de maneira síncrona através da plataforma Zoom e assíncrona através do Ambiente Virtual Moodle, em dois módulos de $30 \mathrm{~h}$. O objetivo geral concentrava-se em despertar de forma espontânea o 
interesse pela língua italiana e, consequentemente, fazer com que os alunos pudessem conhecer mais sobre uma nova cultura, suas histórias e diversidades.

\section{Os desafios e o papel do professor do ensino remoto}

Nos últimos tempos, deparamo-nos com uma realidade inesperada. A pandemia do novo Coronavírus mudou nossas vidas em diversos âmbitos, e a educação não ficou de fora. O modo de ensinar e aprender que conhecíamos, que nos oportunizava, antes de tudo, o convívio social e a troca de experiências na interação face a face deu lugar para a tela do computador, onde, se quisermos, podemos ver sem sermos vistos, e podemos aprender enquanto realizamos outros afazeres. A nova sala de aula pode ser levada ou aberta em qualquer lugar onde tenha conexão com a internet.

O ensino remoto nos traz, porém, desafios diferentes daqueles da sala de aula presencial. A dinâmica é outra e até o tempo parece não ser o mesmo. Tem-se a impressão de que tudo passa muito mais rapidamente e de que todo momento deve ser aproveitado. Alguns segundos de silêncio podem parecer constrangedores, e o professor sente-se responsável por manter o dinamismo da aula e preencher todos os seus "espaços sonoros", o que é cansativo e, muitas vezes, pode fazer com que o aluno não ocupe o espaço que é seu. A sala de aula virtual também permite que o aluno não se mostre. Em um ambiente de ensino presencial, o aluno pode não falar ou participar efetivamente da aula, mas a sua presença física e a sua comunicação não verbal são indícios da sua participação, o que dá ao professor, mesmo de forma ilusória, a sensação de dever cumprido na transmissão do conhecimento. Quando em uma sala de aula virtual, o aluno pode escolher não abrir a câmera para mostrar a sua imagem ou estar impedido de fazê-lo, o que provoca no professor uma leve sensação de incômodo. Por outro lado, o que fica mais difícil de diagnosticar nesse modelo de ensino são as condições em que o aluno se apresenta naquele momento da aula, justamente por não vê-lo: ele pode estar doente e estar fazendo esforço para participar da aula, algo que no presencial não poderia fazer; pode estar, concomitantemente, auxiliando os filhos em suas atividades remotas, auxiliando algum familiar doente, pode simplesmente estar de pijama, dentre tantas outras possibilidades que se apresentaram ao longo da nossa experiência por meio dos relatos dos alunos.

Administrar esses sentimentos e dosar o impulso de tomar para si uma parte maior que aquela que lhe cabe talvez sejam os maiores desafios para os professores de aulas remotas. Manter o interesse dos alunos e fazê-los participar ativamente da aula também não são tarefas fáceis. E quando se fala no ensino de línguas estrangeiras, a interatividade nas aulas é algo imprescindível para alcançar o objetivo. Muito já se falou sobre diferentes métodos e abordagens para o ensino de LE, mas foi no Pós-método que encontramos a figura do professor autônomo com a qual nos identificamos. No seu artigo A era do pós-método: o professor como intelectual, Gisvaldo Araújo Silva (2004) retoma do linguista Kumaradivelu a definição desse professor que, apesar de conhecer as teorias relativas a esses métodos e abordagens, não se prende a ne- 
nhuma fórmula específica, mas procura adequar a sua forma de ensinar a cada classe, levando em consideração aspectos externos como contexto político, socioeconômico e objetivos dos alunos quanto ao aprendizado. Conforme Bunn (2020, p. 10), "velados em nossas atividades estão os conceitos que nos guiam e os modos como os articulamos serão tão mais consistentes quanto mais pensarmos e sermos criativos". Assim, entra em cena o professor que busca entre as ferramentas conhecidas aquelas que melhor servem para a sua prática em sala de aula, embebidas pelos conceitos em que acredita, buscando atividades que funcionam mais para o perfil dos seus alunos, principalmente no contexto remoto. Esse docente é definido por Silva (2004, p. 13-14) como o professor intelectual, que

deve conhecer a teoria e, a partir de sua prática, ser capaz de refletir sobre o seu contexto, desenvolvendo uma abordagem coerente, esclarecida e que é capaz de se reconstruir e se adaptar às situações, aos contextos e aos objetivos específicos daquela comunidade.

A figura do professor intelectual não poderia ser mais requisitada do que neste momento de adaptação à realidade compulsiva das aulas remotas. Não bastasse ter um bom conhecimento dos aspectos linguísticos e tecnológicos que envolvem uma aula de LE de forma remota, o professor precisa fazer com que os alunos se sintam acolhidos, além de conscientizá-los da sua responsabilidade no seu processo de aprendizagem, de sair da posição de mero receptor do conhecimento para aquela de construtor partícipe do processo. Isso, porém, não é tão simples quanto parece. Ao se colocar na posição de receptor das informações, o aluno se coloca hierarquicamente em posição inferior, o que lhe é cômodo, pois assim pode esperar que outro, o professor, seja o responsável pelo seu aprendizado. Fazê-lo perceber que somente seu engajamento o fará realmente aprender é algo necessário ao processo e é possível trabalhar essa questão com o uso das Metodologias Ativas de ensino.

\section{As Metodologias Ativas}

Na sua dissertação de mestrado Metodologias Ativas de Ensino-Aprendizagem (2019), Taciana da Silva Santos cita a definição de Paulo Freire sobre o que é uma metodologia ativa. O educador a define como

uma concepção educativa que estimula processos de construção de ação-reflexão-ação em que o estudante tem uma postura ativa em relação ao seu aprendizado numa situação prática de experiências, por meio de problemas que lhe sejam desafiantes e lhe permitam pesquisar e descobrir soluções, aplicáveis à realidade (FREIRE, apud SANTOS, 2019, p.7)

Dessa forma, as metodologias ativas se distanciam do método de ensino tradicional, pois nessa abordagem a aula é planejada para tirar o aluno da passividade, trazendo-o para o papel 
de protagonista no seu percurso de aprendizagem, tornando-o muito mais significativo. Assim, o professor não é o detentor do conhecimento, mas um mediador e parceiro do aluno, e lhe dá a oportunidade de participar da construção do conhecimento, e com o qual o próprio professor aprende. Quando o aluno se sente partícipe dessa construção, seu engajamento com o próprio aprendizado é muito maior, resultando em mais responsabilidade e confiança, tornando-o capaz de conectar ideias e conceitos que antes pareciam não ter ligação. $\mathrm{Na}$ aprendizagem com as Metodologias Ativas, o aluno desenvolve o senso crítico e reflete sobre sua autonomia e seu papel no processo, tirando do professor a responsabilidade de "lhe ensinar". O professor, por outro lado, passa a conhecer melhor o aluno, podendo focar nas suas fragilidades e dificuldades de aprendizado, pois, em oposição ao ensino tradicional, que é automatizado e generalizado por tratar todos os alunos como se fossem iguais, esse tipo de processo de ensino é mais individualizado, personalizado. Dentre as Metodologias Ativas estão a sala de aula invertida e a gamificação/ludicidade, recursos esses usados como base para a preparação do projeto.

\section{A sala de aula invertida}

Alguns estudos anteriores já haviam abordado a Sala de Aula Invertida, mas foi com os educadores Aaron Sams e Jonathan Bergmann, em 2007, que esse conceito começou, de fato, a ser explorado e aplicado na escola. Ambos buscavam estratégias de ensino para amparar os alunos que não podiam participar das aulas por longos períodos, pois boa parte deles eram atletas ou moravam distantes. Em uma entrevista concedida ao portal Desafios da educação, Bergmann argumenta que: "a sala de aula invertida está mudando a maneira como pensamos a educação. Digo que ela é uma meta-estratégia que apoia todas as outras, porque dá aos professores algo que pode parecer difícil de dimensionar: tempo" (LACERDA, 2018), ou seja, trata-se de uma aposta que viabilizou melhorias tanto para o aluno quanto para o professor, já que o permite dar conta do conteúdo a ser transmitido previamente e abordar em sala de aula questões centrais.

No campo educacional, a abordagem da Sala de Aula Invertida, também identificada em inglês por Flipped Classroom, ou em italiano como Classe Capovolta, vem ganhando certa notoriedade. A metodologia, baseada na essência do ensino híbrido, possibilita a união entre o ensino presencial e a distância, prevê a inversão do ciclo tradicional de aprendizagem composto por aulas frontais, estudo individual em casa ou provas em sala de aula. Segundo Bergmann (2016), existem evidências incontestáveis de que a Sala de Aula Invertida funciona, pois existem mais de 500 artigos publicados em revistas acadêmicas que comprovam a eficácia desse método.

No modelo da Sala de Aula Invertida, existe uma mudança no processo tradicional da sala de aula a que todos estão acostumados, afinal, o aluno é instigado a buscar o conhecimento que o professor disponibiliza antes do encontro presencial. $\mathrm{O}$ aluno, que antes pertencia a uma condição passiva, cujo papel era absorver todas as informações e utilizá-las apenas em momentos pontuais da sala de aula, tais como trabalhos em grupo, provas e reflexões, passa a 
ser visto como um protagonista, sendo colocado, de fato, à frente do seu processo de aprendizagem, enquanto o professor faz a mediação do processo de estudo. Diante das possibilidades e estratégias que a Sala de Aula Invertida fornece, este projeto busca aplicar a metodologia integralmente on line, a fim de que se possa dar uma maior autonomia ao aluno e, também, explorar esta proposta de ensino em um contexto não híbrido. Portanto, a ideia principal foi a de criar um ambiente guiado, na plataforma Moodle, no qual o aluno encontrasse previamente os materiais a serem vistos em aula síncrona para que neste momento pudesse se concentrar nas dúvidas e dificuldades. Entretanto, foi necessário flexibilização e organização da parte dos professores e autodisciplina da parte do aluno, afinal, esta metodologia é uma via diferente da que estamos acostumados a seguir.

\section{A ludicidade no ensino remoto de italiano}

Dentro das Metodologias Ativas está presente também a ludicidade, contextualizada no objeto de aprendizado. Vale ressaltar que o lúdico não está presente somente em brincadeiras que envolvem expressão corporal, mas em todas as "atividades ou vivências que estimulam a imaginação e a criatividade por intermédio de danças, músicas, vídeos, teatralização, poemas e jogos" (VIAL, apud SOUZA e SALVADOR, 2019). A atividade lúdica contribui para o desempenho do professor com formas criativas e dinâmicas para envolver o estudante no aprendizado de diferentes temas e conteúdos, trazendo para a sala de aula a alegria de brincar, seja com jogos de linguagem ou com jogos de movimento (BUNN, 2020). Tal ação traz consigo a memória da leveza da infância, quando o aprender era intrínseco ao crescer. O lúdico, então, remete a uma época em que brincar e aprender ao mesmo tempo era permitido e natural, tirando o peso do aprendizado por meio da apresentação de conteúdos meramente cognitivos.

Assim, quando falamos em aprendizado de LE, o lúdico se constitui em um importante elemento motivador para a interação dos alunos, tão desejada pelo professor. Uma das expressões lúdicas mais exploradas nos tempos do ensino remoto é a Gamificação, que pode ser feita através do uso de plataformas digitais ou da aplicação de atividades com recursos elaborados pelo professor, visando romper a passividade do aprendiz. No seu texto Jogando para aprender: o lúdico no ensino de línguas, Gisele Domingos do Mar (2002, s/p) ressalta que "a aplicação de jogos nas aulas de língua estrangeira serve como elemento de apoio, de incentivo, de interação, de uso efetivo de língua oral ou escrita e de desenvolvimento de habilidades". Para a autora, o jogo contribui para que os alunos adquiram autoconfiança e percam o medo de se expor, além de gerar o sentimento de pertencimento ao grupo. Ao sentir-se parte de um grupo, o estudante se dá conta do papel que exerce na construção do seu objetivo conjunto e busca no seu processo de aprendizado as ferramentas para melhor fazê-lo. Então, ao conscientizar-se de sua responsabilidade com o grupo, o aluno aumenta o seu comprometimento com o próprio aprendizado, resultando em sua melhoria. Portanto, as propostas de atividades para as aulas síncronas do projeto de docência tiveram como base o 
lúdico em prol da interação, visando a aproximação dos professores e alunos, criando, assim, um ambiente de confiança mútua.

\section{Contextualização e propostas de atividades}

As propostas de atividades realizadas foram apresentadas de diversas formas e pensadas, em sua maioria, para proporcionar um ambiente de confiança e descontração para os alunos. De acordo com Pessolano (2018, p.4), o uso da ludicidade é o momento propício para que o professor incentive os alunos a perderem o medo de falar e, assim, praticar seus conhecimentos linguísticos interiorizados e favorecer a interação. Diante deste cenário, foram elaboradas atividades lúdicas que visavam, principalmente, a interação dos alunos. Visto que o projeto foi realizado integralmente on line, foi necessário conhecer novas ferramentas e/ou adaptar atividades já utilizadas no ensino presencial.

Logo, a preocupação com a interação e atenção dos alunos se intensificaram. A ideia de trabalhar o lúdico leva em consideração o processo de ensino-aprendizagem cíclico e não linear, conforme afirma Fernandes (2017, p. 68), "os alunos não aprendem da mesma maneira e no mesmo momento, eles apresentam diferentes maneiras de raciocínio, portanto, devemos proporcionar aos alunos várias estratégias de aprendizagem”. Sendo assim, ao longo do planejamento das aulas, tornou-se indispensável a busca por estratégias que chamassem a atenção dos alunos e despertassem o interesse de participar ativamente delas.

As aulas síncronas foram previamente planejadas e as atividades exemplificadas para que fossem visualizadas antes da prática, de modo a poder chegar mais perto do objetivo principal - a interação dos alunos. Para cada aula foi elaborado um plano de aula que era enviado para a orientadora do estágio, a qual o devolvia com sugestões para melhorias. Seguindo o mesmo fluxo, para avaliar o pós-aula foram feitos relatórios individuais em que se avaliava os resultados gerais e a performance de cada professor.

Os encontros aconteceram uma vez por semana, totalizando 11 encontros síncronos com duração de $1 \mathrm{~h} 30$ referentes aos dois semestres, os quais foram feitos pela plataforma Zoom Meetings. Os alunos participavam pelo computador ou celular e, muitas vezes, não ligavam as câmeras ou alegavam problemas no microfone. Algumas dessas barreiras eram trabalhadas na construção da aula, justamente para diminuir essa distância e buscar a presença do aluno de outras formas, como via chat, por exemplo, descrito adiante. As unidades eram disponibilizadas em média uma semana antes da aula síncrona, os alunos tinham acesso aos conteúdos linguísticos e culturais daquela semana, estudavam e faziam as atividades. Em cada encontro eram destinados 30 minutos para discussão, correção de atividades e dúvidas, em pequenos grupos, selecionados semanalmente, o que permitia que cada estagiário tivesse um momento de maior autonomia com um grupo de trabalho. Para os alunos, além de um ambiente mais personalizado, era possível também um contato mais próximo com os professores.

Uma das ferramentas utilizadas para a apresentação de atividades foi o Wordwall, platafor- 
ma digital que possibilita a criação de atividades temáticas e/ou o uso de atividades já existentes, elaboradas por outros usuários e disponibilizadas para o uso em modo público. Além disso, a plataforma nos permite armazenar as atividades de modo que se possa utilizá-las em sala de aula, bem como compartilhá-las através de um link para que o aluno possa fazê-las sozinho e refazê-las quantas vezes achar necessário. Também foram feitos quizzes interativos por meio dos slides apresentados durante as aulas, assim como foi bem explorado o uso do chat da plataforma Zoom Meetings, uma das grandes formas de interação no ensino remoto, pois permite tanto a interação aluno-professor como aluno-aluno, esta última talvez a mais prejudicada no ensino remoto. As conversas paralelas no chat muitas vezes nos lembravam das eventuais conversas no fundo da sala, no modo presencial. Durante a sua utilização, os professores se dividiram para interagir com os alunos ao longo da aula, a fim de instigar ainda mais a participação, assim como em outras atividades do tipo quebra-gelo. Vejamos algumas atividades propostas:

\section{Trocar o plano de fundo}

Esta é uma atividade do tipo "quebra-gelo" que utilizamos com o objetivo de estimular os alunos a abrirem suas câmeras durante a aula. O Zoom apresenta um recurso chamado Plano de Fundo que possibilita colocar uma imagem de fundo qualquer atrás da pessoa que está sendo filmada. Por um momento, o professor pediu para que todos desligassem suas câmeras e trocassem sua imagem do plano de fundo para uma imagem que remetesse à Itália. Depois de alguns minutos o professor solicitou que todos os alunos abrissem suas câmeras ao mesmo tempo revelando as imagens escolhidas. Alguns fizeram comentários, outros justificaram a escolha. Além do objetivo de aumentar o número de câmeras ligadas durante a aula, essa atividade permitiu que o aluno mostrasse um pouco mais de si, na escolha da imagem. Assim, encontrando-se dentro de um território "demarcado" com a sua identidade, o aluno sentiu-se também mais pertencente ao grupo.

\section{Interação pelo chat}

O chat é uma ferramenta presente em praticamente todas as plataformas de ensino remoto e se faz muito importante para possibilitar a interação escrita em atividades lúdicas. No decorrer deste projeto, este recurso foi usado em várias ocasiões. A presença de mais de um professor durante as aulas permitiu que pelo menos um deles mantivesse acesa a interação pelo chat. Por vezes, o professor que estava ministrando o conteúdo fazia perguntas direcionadas aos alunos e estes escreviam suas respostas no chat. O professor que acompanhava a interação agradecia a participação e fazia comentários escritos, como elogios, sempre utilizando a língua estrangeira. Outras vezes este professor usava o chat para fazer perguntas e fazer comentários relacionados ao tema que estava sendo ministrado no momento. Esse recurso mostrou-se muito profícuo desde as primeiras aulas, desenvolvendo habilidades de escrita e leitura. Mesmo os alunos mais tímidos, que não abriam suas câmeras e não interagiam oralmente, mostraram-se ativos no chat. 
Em uma das aulas foi apresentada a temática cultural "música italiana". O professor introduziu o tema apresentando a imagem de alguns cantores italianos contemporâneos e pediu para que os alunos escrevessem no chat (Figura 1) o nome do cantor que aparecia na figura. Logo em seguida, o professor responsável pela discussão dizia qual era a resposta dos alunos antes que a identidade do cantor fosse revelada. Essa atividade quebra-gelo serviu para inserir os alunos na temática da aula e estimular a interação.

Figura 1 - Print do chat durante uma aula síncrona

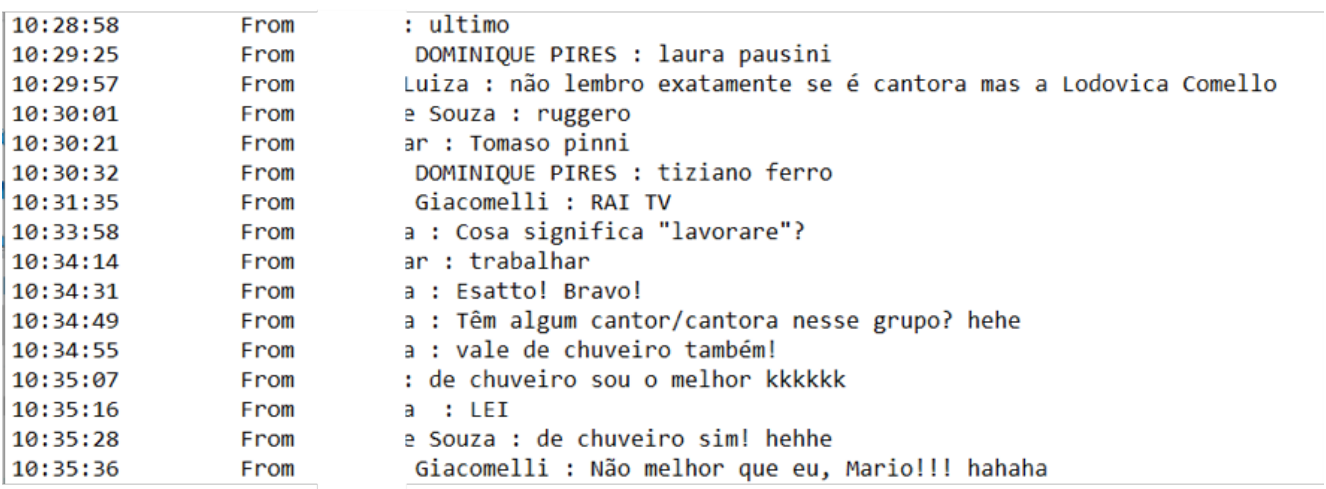

Fonte: Plataforma Zoom Meetings (2020)

Uma outra proposta de atividade prevista com o uso do chat foi idealizada da seguinte maneira: em um slide foram apresentadas quatro perguntas relacionadas à temática cultural da aula, bem como o conteúdo gramatical, que era o uso dos verbos modais do italiano. A atividade foi pensada para ampliar a comunicação na língua alvo, então, a cada frase lida se esperava as respostas dos alunos, que participavam majoritariamente via chat. Entretanto, houve também a participação oral por parte de alguns alunos, o que tornou a dinâmica mais rica, pois ao escutar os colegas, aqueles que estavam apenas participando pelo chat começaram a interagir oralmente também. Para esta atividade, realizada após a apresentação das principais cidades da região norte da Itália, foram feitas perguntas que podem ser vistas na Figura 2. A intenção era a de provocar respostas, a partir de estímulos visuais com pratos típicos regionais, dadas na forma oral e/ou escrita, em que constassem o verbo modal conjugado na primeira pessoa e outros aspectos de caráter pessoal, como, por exemplo: vorrei conoscere Milano; devo assaggiare la pasta al ragù; posso conoscere diversi musei; so cucinare benissimo.

Após a realização da atividade, pudemos avaliá-la como positiva e estimulante, já que os alunos se mostraram entusiasmados em participar e compartilhar suas opiniões e vontades de forma descontraída e lúdica. O uso do chat, como pode ser observado na Figura 3, diante da nossa experiência com o ensino remoto, foi essencial para que todos se sentissem livres para 


\section{Quiz interativo}

Um quiz é um jogo no qual o participante (ou equipe) tenta adivinhar dentre algumas respostas aquela correta para uma questão. É possível criar um quiz online de diversas maneiras, utilizando ferramentas como o Google forms, QuizLet, Wordwall, dentre outros. A maioria deles permite criar atividades competitivas, uma vez que avaliam o desempenho de cada participante e os colocam em um ranking, preceitos que se aproximam da ideia de gamificação. No ensino de LE, o quiz tem inúmeras aplicações. Durante o projeto, usamos algumas vezes com o objetivo de consolidar os conhecimentos já ministrados, e em outras com o objetivo de apresentar questões sociais, históricas, contemporâneas e culturais da língua ou, ainda, com os dois objetivos simultâneos.

Uma das atividades em forma de quiz (Figura 4) foi construída no Wordwall, visando à revisão do uso dos verbos essere, esserci e avere, conteúdo gramatical visto pelos alunos antes da aula síncrona, seguindo a metodologia da sala de aula invertida, e repassado durante o encontro síncrono, nos momentos que precederam a atividade. A atividade consistia em apresentar um slide com uma questão e algumas possibilidades de resposta, para os alunos escolherem aquela correta. Pede-se, então, que os alunos respondam via chat, e que um voluntário responda oralmente. Após as respostas, verifica-se porque as outras eram incorretas, ofertando-se assim, uma outra oportunidade para a assimilação do conteúdo dado. Ao usar o quiz, o professor provoca no aluno o instinto da competitividade, que por vezes pode ser intimidante, mas geralmente mostra-se como um estímulo à participação na atividade.

Figura 4 - Fragmento de uma atividade construída no Wordwall

\section{0 regioni.}

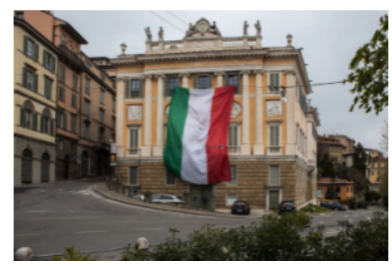

$\equiv$

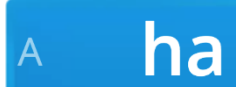

c ci sono

11 de $20 \triangleright$

\section{B C'e}

hanno

Fonte: Wordwall (2020) 


\section{Roda aleatória}

A roda aleatória é uma roleta, que, ao ser girada, randomicamente cai em uma posição. Ela é muito usada em cassinos, nos jogos de azar ou em clássicos da televisão, como o popular "Roda da Fortuna". Na nossa aula, utilizamos a ferramenta Roda Aleatória (Figura 5) disponível na plataforma Wordwall.

Um dos usos desta ferramenta foi pensado para a fixação do conteúdo gramatical l'uso del verbo piacere. O professor preparou uma roda aleatória com locais, comidas (sempre no singular) e atividades (sempre no infinitivo), como por exemplo: il Colosseo, il gelato, vivere in campagna. Então, o primeiro aluno era escolhido, girava a roda e o professor lhe fazia a pergunta sorteada, como no exemplo: João, ti piace il gelato? O aluno, então, respondia: Mi piacel Non mi piace il gelato; depois, ele escolhia um colega para responder a segunda pergunta feita e o procedimento se repetia até que todos tivessem participado. O objetivo dessa tarefa foi o de favorecer a assimilação do conteúdo gramatical, além de estimular a interação e socialização entre os alunos por meio de uma atividade lúdica.

Figura 5 - Print da roda aleatória

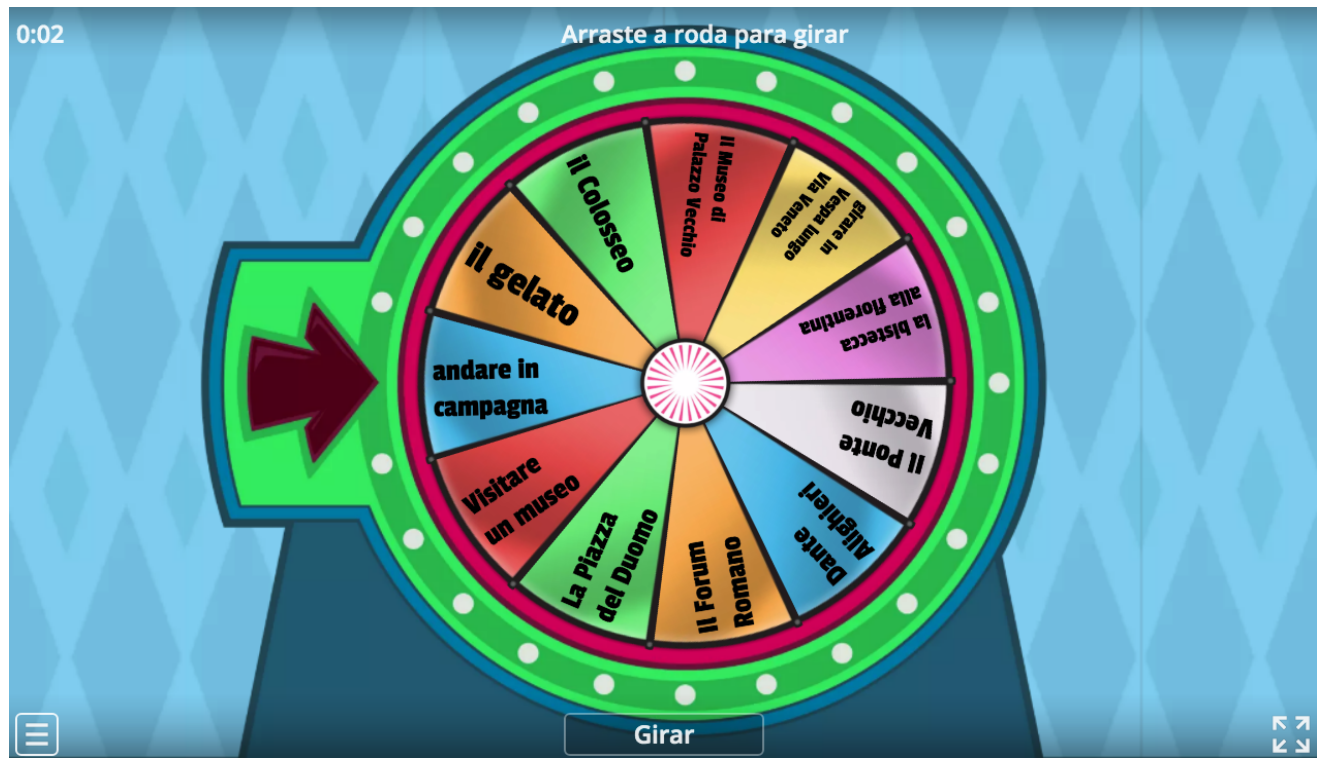

Fonte: Wordwall (2020) 


\section{Simulação de situação real}

Esta atividade foi realizada logo após a apresentação dos artigos partitivos italianos e consistiu na apresentação de slides nos quais constavam produtos encontrados em um bar e em uma padaria italianos. A partir das imagens (Figura 6), o aluno deveria imaginar-se nesses locais, prestes a fazer um pedido, e então, usar um artigo partitivo para fazê-lo (Figura 7). Se quisesse comprar uma quantidade imprecisa de biscoitos, por exemplo, deveria proferir a frase: Per favore, vorrei dei biscotti; se em vez disso quisesse um pouco de café, a frase deveria ser: Per favore, vorrei del caffè. O ato de usar um personagem ou de imaginar uma situação libera, por alguns instantes, o aluno de sua identidade, com seus receios e anseios, permitindo-lhe arriscar-se nesse novo ser. O resultado é uma participação mais efetiva nas atividades.

Figura 6 - Print de uma apresentação de slides

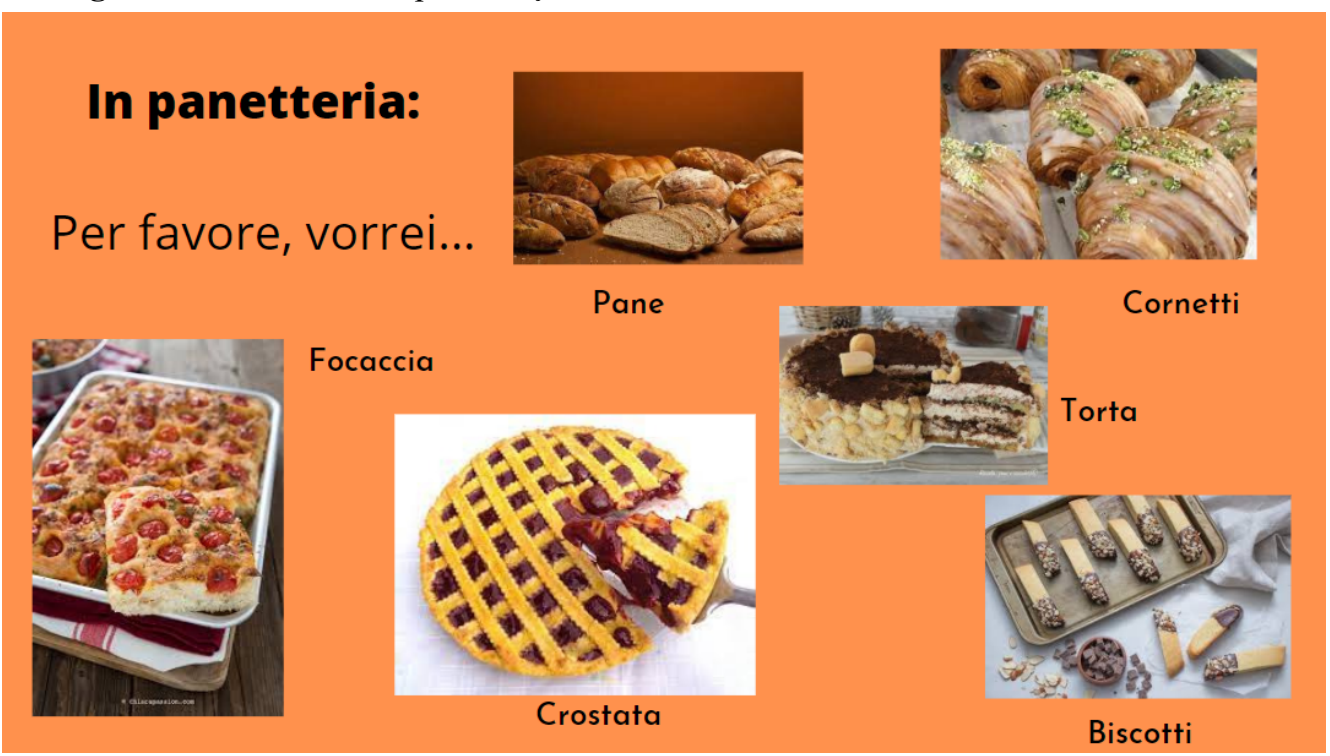

Fonte: Canva (2020) 
Figura 7 - Print do chat durante uma aula síncrona

$10: 42: 56$ From 10:43:06 From $10: 43: 15$ From 10:43:19 From 10:43:21 From $10: 43: 31$ From $10: 44: 08$ From $10: 44: 08 \mathrm{Fro}(\mathrm{r})$ $10: 44: 31$ From $10: 44: 40$ From $10: 44: 50$ From $10: 45: 06 \mathrm{Fr}$

$10: 48: 02$ From

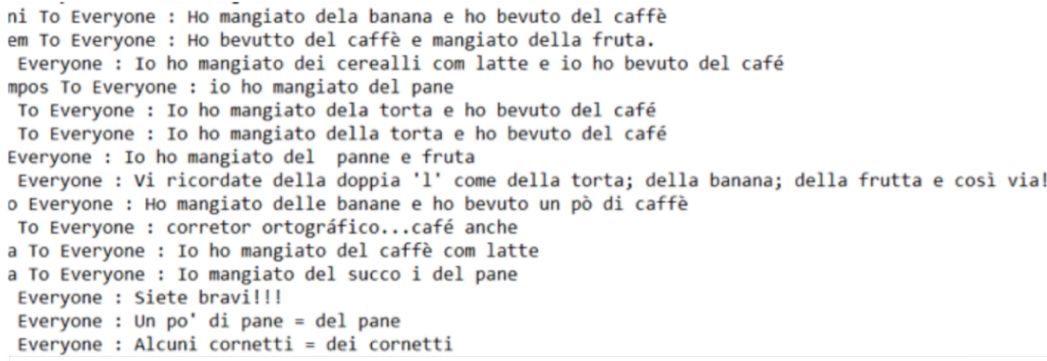

Fonte: Plataforma Zoom Meetings (2020)

\section{Fórum e leitura das autoavaliações}

As últimas atividades apresentadas no segundo curso foram a de um pedido, feito anteriormente no Moodle, para que os alunos se autoavaliassem em italiano e dessem um feedback sobre o curso, sabendo que o texto seria lido durante a aula síncrona. Embora não seja exatamente uma atividade lúdica, está em consonância com o que pregam as Metodologias Ativas, onde os seminários são também muito usados. Para a atividade, o aluno teve de construir um texto em língua italiana (Figura 8), buscando recursos nos conhecimentos adquiridos durante o curso e em outros meios para aumentá-los, a ponto de cumprir a proposta feita pelos professores, numa interação via Fórum. Além de terem praticado a habilidade de expressão escrita, os alunos fizeram a leitura do texto em frente a todos os colegas. Como resultado, houve um grande número de câmeras abertas durante as leituras, momento no qual todos os leitores mostraram seu rosto, incluindo aqueles que nunca o haviam feito. Mais uma vez mostrou-se que quando consciente de sua capacidade de construir, o aluno fica mais confiante e participativo. Em relação ao feedback das aulas, umas das questões mais ressaltadas foi o uso da sala de aula invertida. 
Figura 8: - Print da autoavaliação via fórum

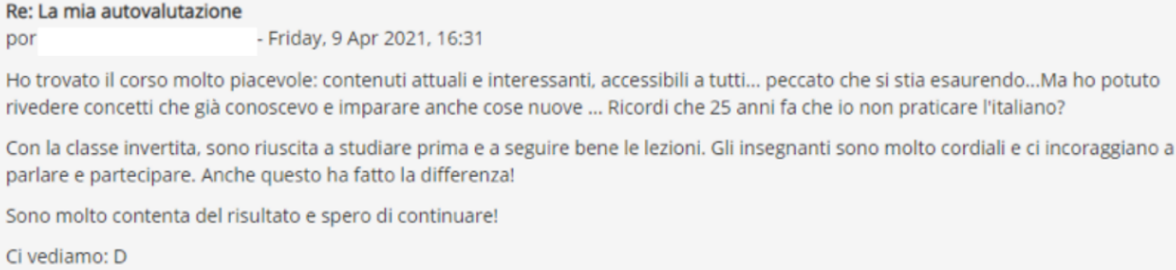

Link direto | Mostrar principal | Editar | Excluir | Responder | Exportar para portfólio

Fonte: Ambiente Moodle (2020)

Tendo em vista as atividades descritas acima e a metodologia utilizada no projeto de docência, pode-se perceber a busca pela aproximação entre professor e aluno diante do ensino remoto e um alto grau de engajamento das duas partes. A criação e/ou adaptação das atividades visaram à descontração e à interação do grupo, para que todos pudessem não apenas colocar o conteúdo previamente estudado em prática como também sanar possíveis dúvidas e compartilhá-las com os colegas. Acreditamos que o lúdico tenha nos auxiliado com o envolvimento dos alunos, a fim de que em cada aula pudéssemos explorar a escrita, como, por exemplo, por meio interação pelo chat; a oralidade através da atividade de simulação real; a escuta em concomitância com a leitura como na atividade de leitura das autoavaliações, que possibilitaram a todos escreverem e lerem em italiano, e também ouvirem uns aos outros. Logo, mediante as escolhas feitas e o uso dessas atividades, alcançamos nosso principal objetivo: fazer com que os alunos se sentissem confortáveis em participar, colaborando, assim, com o processo de aprendizagem de cada um.

\section{Considerações finais}

O ensino remoto começou a crescer no início do século XXI, mas viveu seu boom a partir de 2020, forçado pelas medidas de distanciamento decorrentes da pandemia de Covid 19. Muitos professores viram a necessidade de se adaptarem a esse novo contexto e perceberam que a mera transposição dos conteúdos vistos no ensino presencial ao remoto não era suficiente. A interação do aluno na sala de aula virtual tornou-se um desafio e neste período surgiram muitas 
propostas de atividades lúdicas com o objetivo de proporcionar uma experiência melhor nesse sentido. Muitas delas não tiveram uma experimentação anterior e foram testadas na prática, em sala de aula, e as adaptações foram feitas em tempo real.

Como tantos outros professores, tivemos a necessidade de criar várias atividades, e muitas vezes recriá-las ou adaptá-las à medida em que não atingiam na integralidade os objetivos propostos. Muitas vezes buscamos apoio em ferramentas disponíveis na internet, que na grande maioria das vezes se mostraram eficazes.

Foi através das pesquisas que encontramos dentro das Metodologias Ativas uma infinidade de possibilidades a serem trabalhadas para além do ensino tradicional. $\mathrm{O}$ uso da metodologia da Sala de Aula Invertida contribuiu positivamente para a construção de uma aula mais dinâmica e interativa. Os alunos compreenderam a importância de estudar o material disponibilizado anteriormente e, assim, participaram de forma mais ativa durante os encontros síncronos. Além disso, o conhecimento prévio dos alunos nos possibilitou explorar mais as atividades interativas e usar menos explicações expositivas, a fim de que o lúdico pudesse não só favorecer a interação dos alunos, mas também criar um espaço de trocas e uma maior exposição na língua alvo.

Ao compartilhar nossa experiência, trazemos à luz as contribuições da ludicidade no ensino remoto e apresentamos propostas que possam inspirar professores a refletirem sobre essa forma de tornar o aprendizado mais leve e a criarem e implementarem em suas aulas atividades que consigam unir as Metodologias Ativas de ensino-aprendizado a este novo contexto.

\section{Referências}

BERGMANN, J.; SAMS, A. Sala de aula invertida: uma metodologia ativa de aprendizagem. Rio de Janeiro: LTC, v. 114, 2016. Disponível em: https:/curitiba.ifpr.edu.br/wp-content/uploads/2020/08/ Sala-de-Aula-Invertida-Uma-metodologia-Ativa-de-Aprendizagem.pdf

BUNN, D. Jogos de linguagem e jogos de movimento: deslocamentos lúdicos na aula de língua italiana. Perspectiva - Revista do Centro de Ciências da Educação, volume 38, n. 2 -, abr./jun. 2020, p. 01-14. Disponível em: https://periodicos.ufsc.br/index.php/perspectiva/article/view/2175-795X.2020.e66175.

FERNANDES, A. A. M. O ensino da língua inglesa através da ludicidade. 20 e 21 de outubro de 2017, p. 67.

LACERDA, R. Jon Bergmann explica o conceito de sala de aula invertida. Desafios da Educação, 2018. Disponível em: $<$ https://desafiosdaeducacao.grupoa.com.br/jon-bergmann-e-a-sala-de-aula-invertida/ $>$. Acesso em: 15 de dezembro de 2020.

MAR, G. D. Jogando para aprender: o lúdico no ensino de línguas. In: Congreso Brasileño De Hispanistas, 2, 2002, San Pablo. Anais online. Associação Brasileira de Hispanistas. Disponível em: http:// www.proceedings.scielo.br/scielo.php?script=sci_arttext\&pid=MSC0000000012002000100027\&ln$\mathrm{g}=\mathrm{en} \& \mathrm{nrm}=\mathrm{abn}$.

OLIVEIRA, L. C. Por uma perspectiva plural das línguas estrangeiras na formação escolar. Porto Das Letras, 7(1), 2001, 401-426. Recuperado de https://sistemas.uft.edu.br/periodicos/index.php/portodasletras/article/view/10009. 
PESSOLANO, J.; DALLA CORTE, M. Uma interface entre cultura, motivação e ludicidade no ensino de línguas. Linguagens \& Cidadania, v. 3, n. 2, 2001. Disponível em: https://periodicos.ufsm.br/LeC/ article/view/31512

SANTOS, T. S. Metodologias ativas de ensino-aprendizagem. 2019. Dissertação (Mestrado profissional em educação profissional e tecnológica) - Instituto Federal de Educação, Ciências e Tecnologia de Pernambuco, Olinda, 2019, disponível em: https://educapes.capes.gov.br/handle/capes/565843

SOUZA, J. M. P.; SALVADOR, M. A. S. O lúdico e as metodologias ativas: possibilidades e limites nas ações pedagógicas. Rio de Janeiro: Imperial Editora, 2019. Disponível em: https://www.cp2.g12.br/ blog/mpcp2/files/2017/02/Produto-Juliana-Marques-2019.pdf

SILVA, G. A. A era do pós método: o professor como intelectual. Linguagens \& Cidadania, v. 6, n. 2, jul/dez, 2004. Disponível em: https://periodicos.ufsm.br/LeC/article/view/28979

VALENTE, J. A. Blended learning e as mudanças no ensino superior: a proposta da sala de aula invertida. Educar em revista, n. 4, 2014, p. 79-97.

Recebido em: 12/06/2021 (versão atualizada: 31/08/2021)

Aprovado em: 09/11/2021

Agradecimentos - Agradecemos às professoras Stella Rivello da Silva dal Pont e Denize Nobre Oliveira, bem como ao IFSC, pelo acolhimento de nosso estágio durante a pandemia de Covid-19. 